RESEARCH PAPER

\title{
A comparison of US and Norwegian regulation of coumarin in tobacco products
}

\section{Givel}

Correspondence to: Michael Givel, Department of Political Science, The University of Oklahoma, 455 West Lindsey, Room 205, Norman, Oklahoma 73019 , USA;

mgivel@ou.edu

Received 27 January 2003 Accepted 27 July 2003

\begin{abstract}
Objective: This paper examines policy processes regarding why the USA and Norway have not regulated coumarin in tobacco.

Design: A qualitative analysis of all tobacco industry documents regarding coumarin since the 1950s from the 1998 US Master Settlement Agreement and subsequent legal settlements. Additional data were collected from newspaper reports, general internet search engines, journal articles, scholarly reports, court cases, statutes, regulations, and informal correspondence with tobacco control experts in Norway.

Main outcome measure: An overview, summary, and analysis of all documents related to coumarin.

Results: In the USA from 1954 until 1985 when coumarin was reportedly removed from domestic cigarettes, but not from pipe tobacco until 1996, and not at all from imported Indian bidi cigarettes, regulatory efforts were stymied. In Norway, from 1973 to the present, the tobacco industry has never disclosed whether its tobacco products contain coumarin. In both the USA and Norway, the extreme delay and lack of vigorous evidence gathering and significant remedies were caused by tobacco industry assertions that revealing tobacco additives was a violation of trade secrets, and by weak regulatory authority and efforts to regulate coumarin.

Conclusion: Vigorous and expeditious regulatory investigations and remedies for harmful additives in tobacco, such as coumarin, can protect the public health. Astute insider and outsider political advocacy by health advocates is required to hold elected officials and civil servants publicly accountable for failing to enact disclosure laws and to engage in effective regulatory efforts.
\end{abstract}

oumarin, which was first extracted from tonka tree beans in 1820, has long been used by the tobacco industry as an additive in cigarettes. ${ }^{1-3}$ The taste of coumarin, which is like "new-mown-hay" has been considered by the tobacco industry to be an important additive that significantly enhances the taste. ${ }^{45}$ Despite its flavour enhancing properties, numerous studies, beginning in 1855 , have indicated that coumarin has toxic effects on the nervous system, heart, blood vessels, and liver of animals ${ }^{6-26}$ as well as inducing cancerous tumours and toxic conditions in humans. ${ }^{27} 28$

In 1954, the US Food and Drug Administration (FDA) banned coumarin in food, but not tobacco products, in the USA based on the results of animal research, including the Hazelton study. ${ }^{3} 2026$ Also, since 1954, many European countries have either banned or greatly restricted coumarin because of its toxic properties. ${ }^{30}$ In Norway, like the USA, coumarin has been banned in food, but not in tobacco. ${ }^{31} 32$ This paper is an examination and comparison of the policy processes involved regarding why the USA and Norway have not regulated coumarin in tobacco.

Despite this lack of regulation of coumarin in tobacco in the USA and Norway, internal tobacco industry documents indicate that industry scientists were conducting ongoing experiments to replace coumarin as a primary flavouring in cigarettes as early as the 1960 s. $^{33}{ }^{34}$ Due to public pressure and government requests to disclose cigarette additives, the tobacco industry was supposed to have voluntarily ceased using coumarin in cigarettes in the USA in 1985..$^{55-38}$ However, despite known severe toxic and carcinogenic risks to humans, coumarin was also reportedly used as an additive in pipe tobacco in the USA at least as late as $1996 . .^{35}{ }^{36-41}$ The reported voluntary removal of coumarin in domestic cigarettes in the USA since 1985 (with one report of one brand containing coumarin in 1991) was due to federal regulatory oversight and widespread public efforts to require that the tobacco industry privately disclose to the US government (due to corporate trade secret considerations) tobacco additives. Despite the reported removal of coumarin from domestic cigarettes, coumarin has been reported to be at high levels in imported Indian bidi cigarettes sold recently in the USA. ${ }^{23}$

In Norway, there has been, as of December 2002, an ongoing effort to require the tobacco industry to publicly disclose tobacco additives. ${ }^{31}{ }^{42-44}$ Despite the overwhelming evidence of severe health risks related to coumarin, highly public efforts by the Ministry of Health in Norway have been stymied because of tobacco industry assertions that revealing tobacco additives would be a violation of corporate trade secrets (as in the USA). Because the tobacco industry claims that tobacco additives, including coumarin, were immune from public disclosure as corporate trade secrets, full disclosure and regulation to protect the public health was significantly delayed for at least thirty years in the USA and has not yet occurred in Norway.

\section{METHODS}

I examined tobacco industry documents published on the internet as a result of the 1998 Master Settlement Agreement between 46 attorneys general and the tobacco industry.45 Under the terms of the agreement, five tobacco companies, the Tobacco Institute, and the Center for Tobacco Research created seven searchable web sites. Contained within these web sites are millions of pages of previously secret internal

Abbreviations: EU, European Union; FDA, US Food and Drug Administration; HHS, US Department of Health and Human Services; NTDC, Norwegian National Tobacco Damage Control 
tobacco industry documents. (These web sites are available at: http://www.cdc.gov/tobacco/industrydocs/).

Search terms (including Boolean search phrases) in which 2004 hits occurred included: coumarin, deer tongue, tonka bean, Hazelton, coumarin and research, coumarin and Norway, coumarin and Norwegian, Felleskontoret, National Council on Smoking and Health, NCSH, coumarin and toxic, coumarin and ingredient, coumarin and toxicity, coumarin and pipe tobacco, coumarin and removal, coumarin and FDA, coumarin and Food and Drug Administration. Although all tobacco industry sites were searched, the Philip Morris, American Tobacco Company, RJ Reynolds, and Brown \& Williamson Tobacco Company web sites provided most of the relevant documents. My primary focus was to review all documents referencing coumarin from the 1950s to the present. Additional data were collected from US and Norwegian newspaper reports, general internet search engines including www.google.com, journal articles, scholarly reports, court cases, statutes, regulations, and informal correspondence with tobacco control experts in Norway.

\section{RESULTS}

\section{Health effects of coumarin}

There is a broad consensus in the scholarly research, beginning in the mid 1800s, on the toxic effects of coumarin on animals. In 1875 and 1877, Kohler found that coumarin causes coma and death (including liver deterioration and blood vessel dilation) in a variety of warm and cold blooded animals. ${ }^{67}$ More recent studies have continued to verify that coumarin causes severe liver deterioration in animals. 3252646 Other research has indicated that coumarin has an inhibitory effect on the hearts of frogs and toads and dilates the peripheral blood vessels of frogs and rabbits. ${ }^{11-13}{ }^{15}{ }^{17-19}$ Coumarin has also been found to have a depressive and narcotic effect on frogs, rats, rabbits, and dogs. ${ }^{90}$ In 1956, Hazelton also found coumarin to cause liver and kidney damage in dogs. ${ }^{20}$ Coumarin has also been observed to cause toxic effects, including tumours, in humans. ${ }^{27}{ }^{28}$ In addition, pyrolysed tobacco ingredients, such as coumarin, go directly into human circulatory systems unhindered by the body's normal detoxification processes and are often more toxic than the original substance. ${ }^{21} 2224$

\section{History of coumarin regulation in the USA}

In September 1953, the FDA conducted a hearing to determine the extent and health effects of coumarin in food sold in the country. ${ }^{47}$ Testifying at the hearing as a result of his recent research on the toxic effect of coumarin on dogs was Dr Louie Hazelton of Hazelton Laboratories. ${ }^{47}$ As a result of the Hazelton study, which confirmed the toxic properties of coumarin on animals noted in previous studies, and the FDA hearing, coumarin manufacturers voluntarily removed coumarin from food. ${ }^{3}$ The FDA agreed with this action and issued a notice in 1954 officially removing coumarin from food. ${ }^{3}{ }^{48}$ However, the health effects of coumarin in tobacco products was not considered because the FDA does not have regulatory jurisdiction over tobacco products. ${ }^{4}$ As a March 1954 British-American Tobacco Company memorandum to Brown \& Williamson Corporation attorney, TM Wade, obtained from the Minnesota Tobacco Depository indicated:

I thank you for your letter of 22nd March regarding the use of Coumarin in tobacco manufacture. It is reassuring to learn that the ban on this product clearly does not extend to tobacco and that no action is contemplated in this respect. It seems a pointer, also, that the Tonka [from which coumarin is extracted] market in New York has not been affected. ${ }^{49}$
Publicly the tobacco industry claimed that any associations between coumarin and health affects were either obscure or unproven. ${ }^{4}$ Despite the lack of regulatory prohibition of coumarin in tobacco products, shortly after the issuance of the FDA rule banning coumarin in food, secretly and behind the scenes, the tobacco industry began testing for a possible potential substitute for coumarin. ${ }^{2} 3334$ 49-58

In spite of the search for coumarin substitutes, in November 1965 ( 11 years after the FDA ban of coumarin in food), all five major tobacco companies continued to use coumarin in their cigarettes. ${ }^{50}$ By 1982 (28 years after the FDA banned coumarin in food), coumarin was still found in various major tobacco company brands, with the exception of Philip Morris. Philip Morris reportedly began removing coumarin from all its domestic cigarette brands in 1976. ${ }^{58} 59$

In January 1983, the Florida Times Union and Mother Jones magazine reported that the plant deer tongue, from which coumarin is extracted, was being sold and shipped in large quantities to major tobacco manufacturers. ${ }^{38}{ }^{60}$ In these news articles, the tobacco companies would not comment on whether coumarin from deer tongue was sold in tobacco products because ingredients in tobacco were a "trade secret". ${ }^{38} 6061$ The news reports also indicated that the US Department of Agriculture had found large amounts of coumarin in tobacco products in 1973 and 1978, but smaller amounts in $1983 .{ }^{61}$

In reference to these news reports, the US Department of Health and Human Services (HHS) stated that a tentative agreement had been made between the major tobacco manufacturers and HHS to reveal "commonly used" (used by three or more companies) additives. HHS maintained that it had no regulatory authority to enforce the agreement. ${ }^{6162}$ Despite this tentative agreement, the tobacco companies continued to delay providing a complete list of additives due to trade secret concerns. ${ }^{62}$ After continuing negotiations (and finally complying with the ingredient disclosure provisions of the US Cigarette Labeling and Advertising Act of 1964) in 1985, the major tobacco manufacturers finally privately revealed to HHS that it used coumarin (31 years after the FDA banned coumarin in food) in tobacco products. ${ }^{63}{ }^{64}$

After the 1985 disclosure, all major tobacco manufacturers were reported to have removed coumarin from domestic cigarettes. ${ }^{63}{ }^{64}$ However, in 1991, an internal RJ Reynolds tobacco document noted that coumarin, at one point, remained in one brand of its cigarettes. The RJ Reynolds memorandum obtained from the Minnesota Tobacco Depository stated:

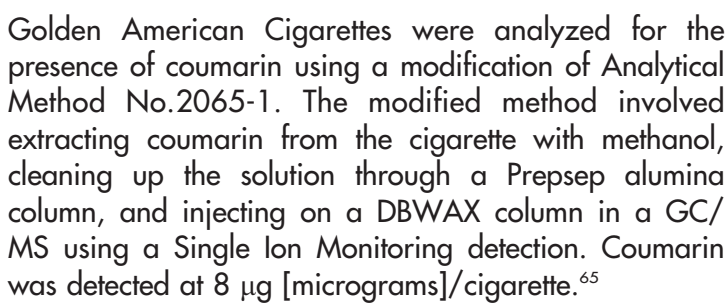

Also, a recent study published in Food and Chemical Toxicology found coumarin in imported Indian bidi cigarettes at levels 8-9 times higher than domestic cigarettes. ${ }^{23}$

In addition, a 1995 deposition in the Mississippi case of Mike Moore, et al. vs. American Tobacco Company, et al. ${ }^{66}$ of Jeffrey Wigand, former vice president for research and development at Brown \& Williamson Tobacco Company, indicated that Brown \& Williamson had continued to use coumarin in pipe tobacco until at least March 1993.35 ${ }^{36}$ An internal industry document from the Minnesota Tobacco Depository by Robert Suber, RJ Reynolds vice president, scientific \& regulatory 
affairs and corporate toxicologist, collaborated this testimony and also indicated three years after Wigand reported that pipe tobacco was sold with coumarin by Brown \& Williamson that:

\section{The major constituent of tonka beans is coumarin. This is the compound that Jeff Wigand talked about on 60 Minutes [a U.S. investigative television programme]. B \& W [Brown \& Williamson Tobacco Company] uses it in their pipe tobacco but not in their cigarettes. ${ }^{41}$}

\section{History of coumarin regulation in Norway}

In March 1973, the Norwegian Parliament enacted Act No.14 of 9 March 1973, Relating to the Harmful Effects of Tobacco. ${ }^{67}$ While the law allowed for the measuring of tar and nicotine yield in cigarettes sold in Norway, it did not require testing of any other additives contained in cigarettes. ${ }^{31}{ }^{67}$ As in the USA, coumarin has also been banned as an additive in food in Norway. ${ }^{68}$

In March 1987, the Norwegian National Council on Smoking and Health informally approached the Norwegian Felleskontoret (tobacco industry) requesting a list of additives contained in cigarettes. ${ }^{68}$ The Felleskontoret indicated that additives in cigarettes were a trade secret and could not be disclosed. ${ }^{42}$ Because of this legal claim, a list of additives was never disclosed. ${ }^{68}{ }^{69}$ According to a March 1987 Philip Morris internal document from the Minnesota Tobacco Depository analysing the implications of this inquiry as well as regulatory efforts at the Norwegian Directorate of Public Health:

\section{The National Council on Smoking and Health is on the track of the substance [coumarin] but so far neither has sufficient knowledge of the substance, nor enough facts on the table to be in a position to press on with the case. In the Directorate of Public Health, work on the problems surrounding additives is given very low priority, and this will delay the process. ${ }^{68}$}

Another internal Philip Morris document from the Minnesota Tobacco Depository in March 1987 analysing regulation efforts of coumarin in tobacco in Norway indicated:

\section{According to P. Danielsen, the health authorities and the National Council of Smoking and Health do not know that certain cigarettes in Norway contain coumarin. Based on the above information I would be thankful if the coumarin issue could be rediscussed with management once the report is available and if we in principal could gain approval to submit a plan on how to capitalize from the situation in Norway. ${ }^{43}$}

Due to tobacco industry trade secret claims as well as informal and low priority efforts to require that tobacco additives be disclosed, such a disclosure never occurred. ${ }^{69}$

After a 1999 disclosure by the Norwegian newspaper Nettavisen that Philip Morris had kept secret that cigarettes in Norway contained coumarin as revealed in documents obtained in the Minnesota Tobacco Depository, ${ }^{43} 68$ the Norwegian National Tobacco Damage Control (NTDC) again requested a full disclosure of tobacco additives in 1999. ${ }^{69}$ Despite this request and public pressure, the Norwegian tobacco industry claimed that it could not provide a list of additives because "It is complicated and there are a lot of substances involved. So I [we] have no answer when the NTDC will get an answer from us" ${ }^{69}$

In 2002, new tobacco control regulations were being drafted by the European Community (EC), including one provision that requires the tobacco industry to supply a list of all additives. ${ }^{31}$ In conjunction with this list, the proposed regulations would require tobacco manufacturers to include toxicological data for each additive. ${ }^{31}$ When the final EC Directive is enacted, implementing legislation by each EC member legislative body will be adopted, including Norway. By December 2002, this Directive had been delayed pending a decision for an exemption for Lichtenstein. If the exemption for Lichtenstein is not approved in 2003, then implementing legislation cannot be adopted in Norway. ${ }^{70}$

\section{DISCUSSION}

Despite the FDA ban of coumarin in food in 1954, the US government was unable to obtain an official list of additives including coumarin in tobacco from 1954 to 1985 (and reportedly up to 1996 for some brands of pipe tobacco) from tobacco manufacturers. This was due to the tobacco industry claiming that tobacco additives such as coumarin were a corporate trade secret along with a lack of significant regulatory investigative powers, administrative and legal penalties, and efforts to compel the industry to disclose additives like coumarin. In further clarifying federal and state regulatory oversight of tobacco ingredients, in December 2002 a US Circuit Court of Appeals ruled that a Massachusetts law that required tobacco ingredient lists with public disclosure of the ingredients was an unconstitutional regulatory taking of property. By contrast, tobacco ingredient disclosure laws which required private disclosure of tobacco ingredients to the US government and Minnesota and Texas have not been challenged by the tobacco industry. ${ }^{71}$

Similarly in Norway, despite coumarin being banned in food, the Norwegian government has been unable to obtain an official list of potential additives, including coumarin, in tobacco from tobacco manufacturers since 1973. Again, this is due to the tobacco industry claiming that tobacco additives are a trade secret along with a lack of significant regulatory and investigative power and actions to compel the industry to disclose the additives.

At issue is the right and ability of a government to protect the public from dangerous or harmful health effects associated with individual tobacco additives, such as coumarin, in conflict with the private property right of maintaining a trade secret to keep a product viable and competitive in the marketplace. While a trade secret that does not cause public harm is usually not open to public scrutiny, a trade secret in which there is actual or potential harm to the public creates a primary necessity for societal oversight and regulation.

As the history and policy lessons of regulatory oversight of coumarin in tobacco in the USA and Norway indicate, governmental regulation requires a process of expediently and vigorously obtaining evidence of coumarin in tobacco and then applying appropriate remedies to counter the potential or actual harm to the public. In order to obtain adequate evidence to ascertain if coumarin is in tobacco (or any other harmful additive in tobacco) agencies can independently and vigorously test for coumarin in tobacco as did the US Department of Agriculture in 1973, 1978, and 1983. Such testing should be standardised worldwide and be wet tested (including by pyrolysis) under laboratory conditions. Testing should also occur for each additive, such as coumarin, both alone and with other chemical components before tobacco is used. 


\section{What this paper adds}

Since 1855, a variety of analyses have documented numerous severe toxic effects of coumarin on animals and humans. Before the release in 1998 of more than 32 million pages of previously secret tobacco industry documents, health advocates could only infer the actual role of the tobacco industry in the USA and Norway in maintaining weak regulatory oversight over controlling coumarin as an additive in tobacco.

Internal tobacco industry documents in conjunction with newspaper and magazine articles, various reports, and journal articles confirm that the tobacco industry in the USA and Norway has engaged in long term campaigns from the 1950 s to the present in order to maintain and benefit from coumarin placement in tobacco products. This campaign by the tobacco industry has been based on the premise that the placement of additives such as coumarin in tobacco could not be regulated to protect the public because they were a "trade secret". The practice of not requiring disclosure or vigorously regulating additives like coumarin was also due to a historic lack of significant regulatory and investigative power and actions by the USA and Norwegian governments to compel the industry to disclose potentially or actually harmful substances like coumarin in tobacco.

Another approach is to provide regulatory agencies with the proper statutory and administrative authority to compel private tobacco companies to expeditiously provide additive lists. If an additive such as coumarin is found on the list (which may be verified through independent governmental or third party testing of tobacco products), then enabling legislation and regulations should exist for a government to counter and remedy this harm to the public.

One remedy may require tobacco manufacturers to administratively cease and desist from adding coumarin in their products. Another remedy may be possible civil or criminal penalties for individuals and companies for violation of product liability, consumer protection, or criminal laws. A final and extraordinary remedy is embodied in the ancient Anglo-Saxon common law principle of quo warranto, or by what authority? In a quo warranto legal action, a lawsuit brought by a government in its sovereign capacity to protect the interest of its citizens may be filed against a corporation, which unlawfully usurps its powers (such as selling tobacco with additives that are toxic or harmful to the public health) granted by the state. The basis of the lawsuit is a remedy to prevent a continued exercise of unlawful activity and authority by a corporate entity such as a tobacco company. ${ }^{72}$

While governments are sometimes prone to engage in such vigorous administrative and legal actions, the opposite has been true with respect to the regulation of coumarin in the USA and Norway. This is where astute political advocacy by health groups is required in order to hold elected officials and civil servants publicly accountable for failing to enact statutes and regulations that provide significant evidence gathering capabilities to identify actual or potential harmful substances such as coumarin in tobacco; and to provide for vigorous administrative and legal remedies in the event that statutes and regulations are violated.

In addition to directly lobbying civil servants and elected officials on an insider basis in the "halls of power" in capitals and government agencies, health advocates, when applicable, should lobby using outsider tactics. Such outsider tactics beyond official institutions of power to pressure legislators and public agencies in conjunction with insider lobbying tactics could include: low cost newspaper advertisements, free media interviews, letters to the editor, community forums with legislators, rallies, supporting legislative supporters and opposing legislative opponents during election campaigns, and public demonstrations. ${ }^{73}$ Without adequate outsider advocacy in conjunction with insider advocacy, vigorous administrative enforcement and penalties to protect the public health related to selling tobacco products with substances like coumarin will probably not occur. Instead, the process of disclosing and exacting remedies for substances like coumarin in tobacco will be dominated by powerful economic interests like the tobacco industry which will delay the process as it hides behind unwarranted claims of "trade secrets".

\section{REFERENCES}

1 Jacobs M. The toxicity of coumarin. The American Perfumer and Essential Oil Review 1953:53-6.

2 Wartman WB. Dolcourin, a coumarin substitute. American Tobacco Company document produced in the case of: State of Minnesota, et al, v. Philip Morris, Inc. et al., No. C1-94-8565, 2nd District Minnesota. Minneapolis: Minnesota Tobacco Document Depository; 3 June 1963. Bates No. ATX02 0004970.

3 Stepka W. Toxicology of coumarin. American Tobacco Company legal document produced in the case of: State of Minnesota, et al v. Philip Morris, Inc. et al., No. C1-94-8565, 2nd District Minnesota. Minneapolis: Minnesota Tobacco Depository; 3 September 1964. Bates No. MNAT00789559-9562.

4 Tobacco Reporter. Coumarin-not good for rats but man uses it differently. Philip Morris legal document produced in the case of: State of Minnesota, et al v. Philip Morris, Inc. et al., No. C1-94-8565, 2nd District Minnesota. Minneapolis: Minnesota Tobacco Depository; June 1969. Bates No. 2000778146-8148.

5 Palmer A, Ikeda RM, Daylor FL. Coumarin in U.S. cigarettes. Philip Morris legal document produced in the case of: State of Minnesota, et al, v. Philip Morris, Inc. et al., No. C1-94-8565, 2nd District Minnesota. Minneapolis: Minnesota Tobacco Depository; 8 February 1983. Bates No. 10031804270437.

6 Kohler H. Die Beeinflussung Der Grossen Korperfunctionen Durch Coumarin. Centralblatt fur die Medicinischen Wissenschaften 1875; 13:867.

7 Kohler H. Eine Thatsachliche Berichtigung Die Vaguslahmende Wirkung Des Cumarins Betreffend. Archiv Fur Experimentelle Pathologie u. Pharmakologie 1877;6:283.

8 Harnack, Witkowski L. Pharmakologische Unterauchungen Uber Das Physostigmen and Calabarin. Archiv Fur Experimentelle Pathologie u Pharmakologie 1876:5:429.

9 Ellinger A. Zur Pharmakodynamischen-dynamischen Charakterisierung Des Cumarins. Archiv Fur Expermintelle Pathologie u. Pharmakologie Suppl. hd. 1908:150.

10 Bergstrom E. Action De La Cumarine Sur Le Systeme Nerveux Autonome. Comptes Rendus Des Saeances De La Sociaetae De Biologie et de Ses Filiales 1925;93:1159-62.

11 Bergstrom E. Recherches Sur Les Proprietes Pharmacologiques Du Coumarin A L'egard Des Organes Isoles Et Mainenus En Survie. Scandinavisches Archiv Fur Physiologie 1928;53:236.

12 Campos FAdM. Contribuicao Ao Estudo Da Accao Pharmacologiea Da Fava Tonka Sobre Systema Muscular. Rev. Flora Med (Rio de Janeiro) 1935; 1:558.

13 Campos FAdM. "Curarization" by coumarin from tonka bean: effect of coumarin on muscular excitability. Annaes (Faculdade de Medicina Universidade de Sao Paulo) 1935;11:165.

14 Marolda Cl. Contribucion al Estudio Farmacodinamico Del Octanol; Accion Sobre El Sistema Circulatorio. Revista de la Associacion Medica Argentina 1936;49:1567.

15 Rai K. Cumarin. Folia Pharmacologica Japanonica 1935;21:86

16 Chen KK, Steldt F, Fried J, et al. The action of simple lactones related to cardiac aglycones. J Pharm Expl Ther 1942;74:381.

17 Giarman NJ. Antibiotic lactones and synthetic analogs. J Pharm Exp/ Ther 1948;94:232.

18 Giarman NJ. Antibiotic lactones and synthetic analogs II. Cardiotic effects on the isolated frog heart. J Pharm Expl Ther 1949;96:119.

19 Walton RP, Cotten M, McCord WM. Absence of digitalis-like cardiac effects in the action pattern of several simple lactones. Proc Soc Exp Biol Med 1950;74:548.

20 Hazelton LW, Tusing TW, Zeitlin BR, et al. Toxicity of coumarin. J Pharm Expl Ther 1956;1 18:348-59.

21 Hoffmann D, Hoffmann I. The changing cigarette, 1950-1995. J Toxicol Environ Health 1997;50:307-64.

22 Bell JAE, Laing DH. Thermodynamic and kinetic variables in tobacco pyrolysis and their influence on their relationship between smoking and health. British American Tobacco Document. San Francisco: University of California-San Francisco; 5 November 1999.

23 Stanfill SB, Calafat AM, Brown CR, et al. Concentration of nine alkenylbenzenes, coumarin, piperonal, and pulegone in Indian bidi cigarette tobacco. Food and Chemical Toxicology 2003;41:303-17.

24 Vorhees D, Heiger-Bernays W, McClean M. Human health risk associated with cigarette smoke: the link between smoke constituents and additives. Boston: The Medical Foundation, 1997. 
25 Christakopoulos A, Feldhusen K, Norin H, et al. Determination of natural levels of coumarin in different types of tobacco using a mass fragmentographic Method. Journal of Agricultural Food Chemistry 1992;40:1358-61.

26 Fever G. The metabolism and biological action of coumarins. Amsterdam: North Holland Publishing Company, 1974.

27 Malewski A. De Camphora, Carbone Sesquichlorato, Cumarino, Vanillique Meletemata [Dissertation]: Dorpat; 1855.

28 Berkanda B, Bouffard-Eyuboglu H, Derman U. The effect of coumarin derivatives on the immunological system of man. Agents and Actions 1983;13:50-2.

29 Watson D. Coumarin. Philip Morris legal document produced in the case of: State of Minnesota, et al, v. Philip Morris, Inc. et al., No. C1-94-8565, 2nd District, Minnesota. Minneapolis: Minnesota Tobacco Depository; 16 April 1981. Bates No. 2001307135.

30 Rylander MR. The toxicology of coumarin. Philip Morris legal document produced in the case of: State of Minnesota, et al, v. Philip Morris, Inc. et al., No. C1-94-8565, 2nd District, Minnesota. Minneapolis: Minnesota Tobacco Depository; 7 September 1981. Bates No. 2023180836-2023180872.

31 Naesheim S. Coumarin in tobacco. Norwegian Directorate for Health and Social Welfare, Department for Tobacco Control, 2002.

32 Dulles F. Norway-Coumarin. Philip Morris legal document produced in the case of: State of Minnesota, et al. v. Philip Morris, Inc. et al., No. C1-948565, 2nd District, Minnesota. Minneapolis: Minnesota Tobacco Depository; Bates No. 2501046311A, 11 March 1987.

33 Waterman WB. Dolcourin, a coumarin substitute American Tobacco Company legal document produced in the case of: State of Minnesota, et al. v. Philip Morris, Inc. et al., No. C1-94-8565, 2nd District, Minnesota. Minneapolis: Minnesota Tobacco Depository; Bates No. MNAT00576924. 7 June 1963.

34 Seligman RB. Coumarin in tobacco. Philip Morris legal document produced in the case of: State of Minnesota, et al. v. Philip Morris, Inc. et al., No. C1-948565, 2nd District, Minnesota. Minneapolis: Minnesota Tobacco Depositoryi Bates No. 2057143630, 30 October 1969.

35 Campaign for Tobacco Free Kids. Wigand is asked whether Brown \& Williamson used rat poison in pipe tobacco; 1995.

36 Wigand JS. Statement of Jeffrey S. Wigand, Ph.D., President of Smoke-Free Kids. In: Public hearings for the Framework Convention on Tobacco Control. Geneva: World Health Organization; 2000.

37 Reynolds RJ. Tobacco Company. Statement on Coumarin. R. J. Reynolds legal document produced in the case of: State of Minnesota, et al. v. Philip Morris, Inc. et al., No. C1-94-8565, 2nd District, Minnesota. Minneapolis: Minnesota Tobacco Depository; Bates No 51711 9527, 1995.

38 Mintz J. Low tar, high risk. Mother Jones 1983:54-6.

39 Kurtz H. Details of unaired tobacco story emerge; cigarette firm ex-official told CBS of cancer causing flavor. Washington Post. 18 November 1995: Sect. $\mathrm{AO} 3$

40 Nye A. Assessment of the use of coumarin as an additive in pipe tobacco. Brown \& Williamson legal document produced in the case of: State of Minnesota, et al. v. Philip Morris, Inc. et al., No. C1-94-8565, 2nd District, Minnesota. Minneapolis: Minnesota Tobacco Depository; Bates No. 503208436-503208452, November 1990

41 Suber R. Tonka beans and PBS documentary. RJ Reynolds legal document produced in the case of: State of Minnesota, et al. v. Philip Morris, Inc. et al., No. C1-94-8565, 2nd District, Minnesota. Minneapolis: Minnesota Tobacco Depository; Bates No. 51742 8707. 13 March 1996.

42 Philip Morris O. Project Coumarin-Top Secret. Philip Morris legal document produced in the case of: State of Minnesota, et al. v. Philip Morris, Inc. et al., No. C1-94-8565, 2nd District, Minnesota. Minnesota; Bates No. 2501046314-6317. 16 March 1987

43 Robinson JB. Norway. Philip Morris legal document produced in the case of: State of Minnesota, et al. v. Philip Morris, Inc. et al., No. C1-94-8565, 2nd District, Minnesota. Minneapolis: Minnesota Tobacco Depository; Bates No. 2501046311A-6312.11 March 1987.

44 Ware K. Coumarin. Philip Morris legal document produced in the case of: State of Minnesota, et al. v. Philip Morris, Inc. et al., No. C1-94-8565, 2nd District, Minnesota. Minneapolis: Minnesota Tobacco Depository; Bates No. 2501046313A. 18 March 1987.

45 National Association of Attorneys General. Master Settlement Agreement; 2002.

46 Lake B, Gray T, Evans J, et al. Studies on mechanisms of coumarin induced toxicity in rat hepatocytes: comparison with dihydrocomarin and other coumarin metabolites. Toxicol Applied Pharmacol 1989:97:311-23.

47 Leahy RL. Notes on coumarin hearing-September 15, 1953. Philip Morris legal document produced in the case of: State of Minnesota, et al. v. Philip Morris, Inc. et al., No. C1-94-8565, 2nd District, Minnesota. Minneapolis: Minnesota Tobacco Depository; Bates No. 2022239064. 17 September 1953.

48 United States Food and Drug Administration. FDA statements of general policy and interpretation. Washington DC: FDA, 1954.

49 Evers HH. Letter to Brown \& Williamson Tobacco Company from British American Tobacco Company. Brown \& Williamson legal document produced in the case of: State of Minnesota, et al. v. Philip Morris, Inc. et al., No. C1-94-
8565, 2nd District, Minnesota. Minneapolis: Minnesota Tobacco Depository; Bates No. 650203426. 29 March 1954.

50 Resnik FE. Coumarin in commercial cigarettes, Philip Morris legal document produced in the case of: State of Minnesota, et al. v. Philip Morris, Inc. et al., No. C1-94-8565, 2nd District Minnesota. Minneapolis: Minnesota Tobacco Depository; Bates No. 2060535675-5677. 11 November 1965.

51 Cohen MB. Production request for Philip Morris Commander cigarettes with and without coumarin project 8205 , study CIN-1. Philip Morris legal document produced in the case of: State of Minnesota, et al. v. Philip Morris, Inc. et al., No. C1-94-8565, 2nd District, Minnesota. Minneapolis: Minnesota Tobacco Depository; Bates No. 1001892964-2965. 30 January 1969.

52 Harlow ES. Status of coumarin research. American Tobacco Company legal document produced in the case of: State of Minnesota, et al. v. Philip Morris, Inc. et al., No. C1-94-8565, 2nd District, Minnesota. Minneapolis: Minnesota Tobacco Depository; Bates No. MNATO0789564-9565. 24 September 1964.

53 Dunn WL. Plans for evaluation of coumarin. Philip Morris legal document produced in the case of: State of Minnesota, et al. v. Philip Morris, Inc. et al., No. C1-94-8565, 2nd District, Minnesota. Minneapolis: Minnesota Tobacco Depository; Bates No. 1000849818. 8 January 1964.

54 Seligman RB. Coumarin substitute. Philip Morris legal document produced in the case of: State of Minnesota, et al. v. Philip Morris, Inc. et al., No. C1-948565, 2nd District, Minnesota. Minneapolis: Minnesota Tobacco Depository; Bates No. 1001888943. 6 September 1968.

55 Kounnas CN, Vinals JF. Elimination and/or replacement of coumarin/ coumarin. Philip Morris legal document produced in the case of: State of Minnesota, et al. v. Philip Morris, Inc. et al. No. C1-94-8565, 2nd District, Minnesota. Minneapolis: Minnesota Tobacco Depository; Bates No. 1001887929-7930. 5 February 1970.

56 Daylor FL. Coumarin. Philip Morris legal document produced in the case of: State of Minnesota, et al. v. Philip Morris, Inc. et al., No. C1-94-8565, 2nd District, Minnesota. Minneapolis: Minnesota Tobacco Depository; Bates No. 2000759709. 20 April 1970.

57 Seligman RB. Status of coumarin (CF) in Philip Morris' tobacco products. Philip Morris legal document produced in the case of: State of Minnesota, et al. v. Philip Morris, Inc. et al., No. C1-94-8565, 2nd District, Minnesota. Minneapolis: Minnesota Tobacco Depository; Bates No. 2022208575. 21 July 1972.

58 Resnik FE. Removal of CF. Philip Morris legal document produced in the case of: State of Minnesota, et al. v. Philip Morris, Inc. et al., No. C1-94-8565, 2nd District, Minnesota. Minneapolis: Minnesota Tobacco Depository; Bates No. 1003722157. 16 June 1976.

59 American Tobacco Company. Coumarin content, market lot cigarettes 1982. American Tobacco Company legal document produced in the case of: State of Minnesota, et al. v. Philip Morris, Inc. et al., No. C1-94-8565, 2nd District, Minnesota. Minneapolis: Minnesota Tobacco Depository; Bates No. MNAT00683417/3418. 29 December 1982.

60 Cummins K. Additive adds to mystery to risk of smoking. Florida Times Union. 12 January 1983:Sect A1-2.

61 Schmid R. Questions go unanswered. Associated Press, 12 January 1983.

62 Cummins K. Cigarette makers slow to give list of all additives. Florida Times Union. 17 January 1983.

63 RJ Reynolds Tobacco Company. Coumarin (91-64-5). R. J. Reynolds legal document produced in the case of: State of Minnesota, et al. v. Philip Morris, Inc. et al., No. C1-94-8565, 2nd District, Minnesota. Minneapolis: Minnesota Tobacco Depository; Bates No. 520991437-1443. 4 March 1998.

64 Daylor FL, Taylor BG. Coumarin. Philip Morris legal document produced in the case of: State of Minnesota, et al. v. Philip Morris, Inc. et al., No. C1-948565, 2nd District, Minnesota. Minneapolis: Minnesota Tobacco Depository; Bates No. 2000777452-7453. 26 July 1985.

65 Wendelboe F. Coumarin in Golden American cigarettes R. J. Reynolds legal document produced in the case of: State of Minnesota, et al, v. Philip Morris, Inc. et al., No. C1-94-8565, 2nd District, Minnesota. Minneapolis: Minnesota Tobacco Depository; Bates No. 51218 0753. 21 January 1991.

66 Mike Moore, et al. vs. American Tobacco Company, et al. Case No. 941429. Chancery Court of Jackson County, Mississippi, 1994.

67 Relating to Prevention of the Harmful Effects of Tobacco; 1973.

68 Danielsen P. TOP SECRET. Philip Morris legal document produced in the case of: State of Minnesota, et al, v. Philip Morris, Inc. et al., No. C1-94-8565, 2nd District, Minnesota. Minneapolis: Minnesota Tobacco Depository; 16 March 1987. Bates No. 2501046314-6317.

69 James A. Will not keep to poison deadline. The Norway Post, 10 August 1999.

70 European Commission. Directive 2001/37/EC of the European Parliamen and of the Council of 5 June 2001 on the approximation of the laws, regulations and administrative provisions of the Member States concerning the manufacture, presentation and sale of tobacco products-Commission statement. 32001L0037; 2001

71 Philip Morris, et alvs. Thomas Reilly, Attorney General of Massachusetts Case Numbers: No.00-2449 and No.00-2425. In: United States Codes Annotated: United States Court of Appeals for the First Circuit; 2002.

72 Garner BA. Black's law dictionary. Deluxe, 7th ed: West Group; 1999.

73 Givel M, Glantz S. Tobacco lobby political influence on US state legislatures in the 1990s. Tobacco Control 2000;10:124-34. 